Sigrid Hemels*

\title{
Opkomst en ondergang van de belastingsubsidies voor de filmsector
}

Tussen 1997 en 2007 was veel te doen over de belastingmaatregelen waarmee Nederland de filmsector wilde stimuleren. Het doel van deze maatregelen was het genereren van productievolume door het aantrekken van private investeringen en het bevorderen van de filminfrastructuur. Aan de overheid staan diverse middelen ter beschikking om beleidsdoelstellingen te bereiken, bijvoorbeeld regelgeving, voorlichting en subsidiëring. Subsidiëring kan plaatsvinden via een directe subsidie, dat wil zeggen via een op de rijksbegroting verantwoorde uitgavenpost, of door een tegemoetkoming in de belastingwetgeving te verlenen: een belastingsubsidie. Waar er bij een directe subsidie eerst geld (belasting) van alle belastingbetalers naar de overheid gaat en vervolgens een subsidie van de overheid naar de subsidieontvangers, ontbreekt bij een belastingsubsidie een fysieke geldstroom tussen de belastingbetaler en de overheid. De belastingbetalers die aanspraak kunnen maken op de belastingsubsidie betalen minder belasting en de overheid derft inkomsten. De einduitkomst is echter gelijk: na ontvangst van de subsidie of toepassing van de belastingsubsidie beschikt de gesubsidieerde/belastingplichtige over meer en de overheid over minder middelen dan zonder de (belasting)subsidie. Belastingsubsidies kunnen diverse vormen aannemen, bijvoorbeeld die van een vrijstelling, een aftrekpost op inkomen, een belastingaftrek (in de Nederlandse inkomstenbelasting vertaald als heffingskorting), een speciaal tarief, uitstel van het belastbare moment of het vervroegd mogen nemen van kosten. Ook op het beleidsterrein van kunst en cultuur bestaan diverse belastingsubsidies.

De belastingsubsidies voor kunst en cultuur die tussen 1997 en 2007 in de pers de meeste aandacht kregen, waren de in 1998 ingevoerde faciliteiten voor de zogenoemde film-cv's. Een film-cv is een commanditaire vennootschap (een juridische samenwerkingsovereenkomst) waarin een film wordt geproduceerd. Deze filmfaciliteiten stonden model voor het failliet van belastingsubsidies als stimuleringsmaatregel. Het beslag op de schatkist bleek vele malen hoger dan verwacht, er lekte veel geld weg naar adviseurs en uit evaluaties bleek dat de belastingsubsidies niet efficient en effectief waren. Door de sterke filmlobby lukte het echter niet om deze ineffi-

* Sigrid Hemels (I973) is hoogleraar Belastingrecht aan de Erasmus Universiteit Rotterdam. Een deel van haar onderzoek is gericht op de fiscaliteit van kunst en cultuur, hetgeen onder meer is uitgemond in het boek Kunstliefhebbers, culturele instellingen en belastingen (Amersfoort 2008). Tevens is zij werkzaam in de fiscale praktijk van Allen \& Overy llp in Amsterdam. E-mail: hemels@frg.eur.nl 
ciënte belastingsubsidies af te schaffen. Pas toen het budget voor de belastingsubsidies werd overgedragen aan het ministerie van OCW, konden de fiscale faciliteiten medio 2007 ten grave worden gedragen. In deze bijdrage bespreek ik de opkomst en ondergang van deze belastingsubsidies voor films en beantwoord ik de vraag waarom deze niet brachten wat ervan werd verwacht.

\section{Film-cv avant la lettre: ZUSJE}

Dé verrassing van het Nederlands Film Festival 1995 was de film ZUSJE van Robert Jan Westdijk. Dit was niet alleen in filmtechnisch opzicht het geval, de film werd bekroond met het Gouden Kalf, maar ook de financiering van ZUSJE was bijzonder. De film was namelijk geheel met private middelen bekostigd: er was geen cent subsidie aan te pas gekomen. De toen nog onbekende filmmaker Westdijk werd hiertoe geïnspireerd door het boek Spike Lee's Gotta Have It: Inside Guerrilla Filmmaking, waarin de filmmaker Spike Lee beschrijft hoe zijn eerste speelfilm SHE GOTTA HAVE IT (I986) tot stand kwam. ${ }^{\mathrm{I}}$ Niet alleen wierven Westdijk en zijn medewerkers sponsoren uit het bedrijfsleven en werkte de 25 man tellende filmploeg voor een percentage dat de film eventueel zou opbrengen, ook werden particulieren, veelal vrienden en kennissen, bereid gevonden om via een fiscaal slimme structuur geld in de film te steken. Op I januari 1994 kwam zo de commanditaire vennootschap ('cv') Grote Broer Filmwerken tot stand die de film zou produceren. Westdijk was als beherend vennoot volledig aansprakelijk voor de eventuele schulden van deze cv. Daarnaast waren 39 particulieren bereid bedragen tussen de duizend en vijfentwintigduizend gulden in de $\mathrm{cv}$ te storten. Deze commanditaire vennoten waren niet persoonlijk aansprakelijk, maar liepen wel het risico hun volledige inleg te verliezen. Van de eventuele winst die de film zou maken, zou 50\% naar de commanditaire vennoten gaan en $50 \%$ naar de acteurs en de crew. Onder de inkomstenbelastingwetgeving tot I januari $200 \mathrm{I}$ werden deze commanditaire vennoten als ondernemers gezien. Dit had een aantal voordelen voor de particuliere geldschieters. Anders dan beleggers, mogen ondernemers hun verliezen namelijk aftrekken van hun (overige) inkomen. Als de film een flop was geworden en de inleg niet zou worden terugbetaald, kon dit verlies bijvoorbeeld in mindering worden gebracht op het salaris dat de particulier verdiende. Gegeven het toenmalige toptarief van de inkomstenbelasting van $60 \%$ (tot I januari 200I), liep een particulier die in dit hoge tarief belast werd derhalve feitelijk slechts maximaal het risico om $40 \%$ van zijn inleg kwijt te raken. De resterende $60 \%$ kon hij in geval van een verlies van de Belastingdienst terugvragen. Daarnaast had de commanditaire vennoot indertijd ook recht op bepaalde belastingsubsidies voor ondernemers, zoals een vrijstelling wanneer de film-cv met winst zou worden beëindigd. Door deze fiscale verzachtingen werd het risico van de particuliere investeerders ingeperkt, maar ze liepen zelf wel degelijk een deel van het risico. Dit was belangrijk, want het geloof dat de particulieren in de film hadden, 
maakte het makkelijker om ook bedrijven te interesseren om de film te ondersteunen, zowel in geld als in natura. ${ }^{2}$

Belangrijke kenmerken van de film-cv waarmee ZUSJE tot stand werd gebracht, waren dat er een persoonlijke betrokkenheid was van de geldschieters en dat zij, ondanks de fiscale faciliteiten, met hun investering risico liepen. Deze elementen waren helaas nagenoeg geheel afwezig bij de latere film-cv's, die niet langer gebaseerd waren op het particuliere initiatief van een regisseur en filmliefhebbers, maar die door de bemoeienis van de overheid een geïnstitutionaliseerd beleggingsproduct werden.

\section{Film-cv geïnstitutionaliseerd in 1998}

De bijzondere financieringswijze van de film ZUSJE trok ook in Den Haag de aandacht. Eind jaren negentig was er een economische opleving, het paarse kabinet had in Willem Vermeend een staatssecretaris van Financiën die niet afkerig was van het gebruik van belastingsubsidies om bepaalde beleidsdoelstellingen te bereiken en de filmsector had een stevige lobby gevoerd voor fiscale ondersteuning. En zo kon het gebeuren dat tijdens het Nederlands Film Festival van 1997 staatssecretaris Vermeend aankondigde dat in 1998 belastingsubsidies voor de filmsector zouden worden ingevoerd. Dit gebeurde uiteindelijk op 7 december I998 met terugwerkende kracht tot I januari I998. 3 De commanditaire vennoot in een film-cv had vanaf I998 niet alleen aanspraak op de ondernemersfaciliteiten die voor alle ondernemers golden, zoals een aftrek voor investeringen en een vrijstelling bij beëindiging van de onderneming, maar mocht daarnaast het bedrag van zijn investering in de film-cv eerder in aftrek brengen dan bij een gewone investering het geval zou zijn. Door deze zogenoemde willekeurige afschrijving kon de belegger in een film-cv zijn belastingvoordeel eerder verzilveren. Om voor de belastingsubsidie in aanmerking te komen, moest het ministerie van Economische Zaken een verklaring hebben afgegeven dat de film primair was bestemd voor vertoning in bioscopen en dat het geen reclame- of voorlichtingsfilm betrof. Andere eisen werden oorspronkelijk niet gesteld. Dit 'pakket structuurversterkende maatregelen voor de filmindustrie', 4 dat overigens veel meer omvatte dan alleen fiscale maatregelen, werd ingevoerd voor een periode van in beginsel vijf jaar. De gedachte was namelijk dat na vijf jaar de extra ondersteuning niet meer nodig zou zijn. De staatssecretaris schreef hierover aan de Raad van State:

'Om de filmindustrie een duw in de goede richting te geven worden maatregelen voorgesteld die zijn gericht op het verbeteren van de financiële en economische infrastructuur, waardoor de investeringsbereidheid en het productievolume kan worden vergroot. De voorgenomen maatregelen betreffen dus niet zozeer een steunprogramma als wel het geven van een impuls aan de filmindustrie.'5 
Het was dus nadrukkelijk een tijdelijke maatregel. Op voorhand kon echter al de vraag worden gesteld of een tijdelijke maatregel voldoende zou zijn om de Nederlandse filmindustrie verder te helpen. Dat de structurele problemen in de sector werden onderkend, blijkt ook uit de nadere motivering voor de belastingsubsidies in de memorie van toelichting bij het wetsvoorstel waarin de invoering hiervan werd voorgesteld:

'Nederland biedt goede mogelijkheden voor een in de economische en culturele infrastructuur verweven bedrijfstak film. De Nederlandse filmindustrie kampt echter met een aantal specifieke problemen. Het commerciële succes van een film is bijvoorbeeld moeilijk te voorspellen. (...) Op een enkele uitzondering na zijn de Nederlandse filmbedrijven te klein en te verbrokkeld om de gemaakte verliezen te kunnen compenseren. Hierdoor is de winstgevendheid van de filmindustrie als geheel te gering, hetgeen leidt tot geringe private investeringsbereidheid. Mede als gevolg van deze negatieve spiraal staat de infrastructuur van de Nederlandse filmindustrie onder zware druk. ${ }^{6}$

\section{De eerste jaren: wild west in de polder}

De film-cv bleek een grote hit en, getuige de grote bedragen die hierin omgingen, een commercieel succes: de belastingsubsidies hadden duidelijk geleid tot een vergroting van het aantal geproduceerde films. Er was echter ook kritiek: de maatregelen stelden geen eisen aan het culturele gehalte van de films; de focus lag primair op commercieel interessante films. Bovendien stelden de in 1998 ingevoerde maatregelen geen eisen aan het Nederlandse karakter van de films die met de belastingsubsidies werden gefinancierd. In 1999 en 2000 zijn 27 film-cv's geactiveerd met 40 films, waarvan er 27 een Nederlandse signatuur hadden. 7 Er was geen minimumeis voor het in Nederland te besteden budget. Dit leidde ertoe dat een groot aantal films met een niet-Nederlandse signatuur met Nederlands belastinggeld tot stand kwam. Zo zou $80 \%$ van het budget van de cv-film LITTLE VAMPIRE in Duitsland zijn besteed. ${ }^{8}$ Ook werd de vraag gesteld wat de ondersteuning van de film ENIGMA met Nederlands belastinggeld rechtvaardigde. Deze film, waarin onder meer Kate Winslet speelde, werd geheel in Engeland opgenomen en had een niet-Nederlandse regisseur (Michael Apted) en cast.

In totaal is er in 1999 en 2000 ongeveer 540 miljoen gulden omgegaan in de cvfilms, waarvan ongeveer 200 miljoen gulden is besteed in de Nederlandse filmsector. Dit terwijl in 1998 werd uitgegaan van een budgettair beslag van de belastingsubsidie van 5 miljoen gulden. ${ }^{9}$ De Volkskrant heeft uitgerekend dat het ministerie van Financiën zo'n 66 euro per bezoeker heeft betaald voor de films die in de jaren I999 en 2000 werden gemaakt. ${ }^{\text {IO }}$ Waar werd dit geld voor gebruikt? De budgetten voor films waren verhoogd van in het verleden rond de 2,5 miljoen naar meer dan 5 miljoen gulden en in enkele gevallen zelfs meer dan 20 miljoen gulden. Dit 
hogere budget kwam ten goede aan betere salarissen, betere technische kwaliteit en investeringen in print en advertenties. Hans Beerekamp, filmredacteur van NRC Handelsblad, schreef: 'In de zomer van 1999 was er zoveel werk in de sector dat de honoraria explosief stegen. De facilitaire bedrijven investeerden fors en nog waren er wachtlijsten voor de huur van lampen en microfoons.' ${ }^{\text {'I }}$ Regisseur Paula van der Oest constateerde in het jaar 2000 dat stagiairs van de Filmacademie op de set 300 gulden per dag verdienden, in tegenstelling tot de maximale 350 gulden per week die zij zelf indertijd kreeg. ${ }^{\text {I2 }}$ Dit had overigens ook negatieve effecten. Scenarioschrijver Frank Ketelaar vreesde dat nooit meer een serie als OUD GELD zou worden gemaakt: 'OUD GELD kostte destijds 650 duizend gulden per aflevering. In die tijd was dat een flink bedrag, maar de afgelopen jaren is alles twee keer zo duur geworden. Dat is een effect van de cv-maatregel, waar je niemand over hoort.' ${ }^{3}$

Een ander punt van kritiek was dat de fiscale maatregelen negatieve effecten hadden op de marktoriëntatie van de filmsector, omdat een film geen commercieel succes hoefde te zijn om een fiscaal succesvol beleggingsproduct te zijn. ${ }^{4}$ Een film die weinig bezoekers trok, kon beleggers door de fiscale voordelen toch een hoog rendement opleveren. Ook leek de productiesector nauwelijks versterkt te zijn. Beerekamp was van mening dat sprake was van een 'stortvloed aan nationale en internationale producties, waarvan de respectieve bijdrage aan de Nederlandse filmcultuur dubieus leek.' ${ }^{\text {I5 }}$

\section{De film-cv in zwaar weer vanaf 2001}

In 200 I braken op diverse vlakken minder succesvolle tijden aan voor de film-cv. In de zomer van 2OOI werd het faillissement van de film OCEAN WARRIOR uitgebreid in de kranten beschreven. Ook begon de filmmaatschappij van Leon de Winter een procedure tegen Delta Lloyd, vanwege het stopzetten van het Delta Lloyd Filmfonds, nadat al eerder door Delta Lloyd een procedure tegen voornoemde filmmaatschappij was aangespannen.

De kritiek op de inefficiënties van de film-cv zwelde bovendien aan. In de herfst van 200I ontstond ook nog eens beroering over de vermoede bemoeienis van de toenmalige staatssecretarissen Vermeend en Van der Ploeg en Kamervoorzitter Van Nieuwenhoven met de cV waarin de film DISCOVERY OF HEAVEN werd gemaakt. De twee laatstgenoemden werden in de aftiteling van de film bedankt, waarna de Volkskrant op onderzoek uitging. Volgens deze krant had Van Nieuwenhoven Vermeend ingelicht over problemen met de Belastingdienst, waarna Vermeend persoonlijk zou hebben ingegrepen. ${ }^{16}$ Persoonlijk ingrijpen van een staatssecretaris van Financiën in zaken van een individuele belastingplichtige is in Nederland hoogst ongebruikelijk. In I985 en I986 is hierover uitgebreid gedebatteerd in het kader van de 'Wibo van der Linde-affaire' (de staatssecretaris van Financiën zou de inspecteur opdracht hebben gegeven de aanslag van de toenmalige AVRO-directeur te verminderen). ${ }^{\text {I7 }}$ Weliswaar heeft de staatssecretaris van Financiën een instructiebevoegdheid in indi- 
viduele gevallen, maar hij wordt geacht hier uiterst terughoudend mee om te gaan. Hij moet in ieder geval voorkomen (de schijn te wekken) bepaalde belastingplichtigen te bevoordelen, omdat dit in strijd zou zijn met het gelijkheidsbeginsel.

Maar in 200I was er ook alom vreugde over het grote aanbod lange speelfilms op het Nederlands Film Festival: door de film-cv's met 22 titels het hoogste aantal in de geschiedenis van het festival. ${ }^{18}$ Dit waren echter merendeels films waarvan de cv in 2000 was gestart. Tegenover de 2I film-cv's die in 2000 waren gestart, stonden er slechts negen in $200 \mathrm{I}$.

De daling van het aantal film-cv's in het jaar 200I is grotendeels te verklaren door de onzekerheid die in dat jaar bestond over de voortzetting van de regeling. Op I januari 200I werd namelijk de Wet Inkomstenbelasting 200I ingevoerd. Deze wet verving de oude Wet Inkomstenbelasting I964. Deze wijziging had grote gevolgen voor de film-cv. Onder de oude wet werd de commanditaire vennoot in een cv als ondernemer aangemerkt, waardoor hij recht had op verschillende ondernemersfaciliteiten. Dit leverde niet alleen beleggers in een film-cv aanzienlijke voordelen op, maar ook beleggers in andere commanditaire vennootschappen. De behandeling van commanditaire vennoten - die feitelijk niets anders dan beleggers waren - als ondernemers, was het ministerie van Financiën een doorn in het oog. Oorspronkelijk was dan ook voorgesteld om commanditaire vennoten voortaan hetzelfde te behandelen als andere beleggers. De inleg in de cv zou daardoor niet langer aftrekbaar zijn. Na grote protesten uit de hoek van de zeescheepvaart-cv's en film-cv's werd dit echter verzacht. Commanditaire vennoten vallen daardoor sinds I januari 200I nog wel onder het winstregime en niet onder het beleggersregime, maar ze worden niet langer als ondernemers, maar als zogenoemde medegerechtigden aangemerkt. Een medegerechtigde geniet wel winst uit onderneming, waardoor hij bijvoorbeeld - anders dan een gewone belegger - verliezen kan aftrekken. Hij heeft echter geen recht op verschillende ondernemersfaciliteiten, zoals de voor film-cv's belangrijke vrijstelling bij beëindiging van de cv. Het nettorendement op filminvesteringen zou door het ontbreken van deze ondernemersfaciliteiten aanzienlijk lager en in de meeste gevallen zelfs negatief worden.

Om beleggingen in films aantrekkelijk te houden, werden nieuwe belastingsubsidies voorgesteld. De nieuwe maatregelen moesten bovendien tegemoetkomen aan de kritiek dat de oude belastingsubsidies onvoldoende ten goede kwamen aan de Nederlandse filmindustrie. Om in aanmerking te komen voor de nieuwe faciliteit moest meer dan de helft van de voortbrengingskosten van de film betrekking hebben op Nederland. Deze eis leverde echter direct een nieuw probleem op: de nieuwe regels konden niet meteen worden ingevoerd, omdat de Europese Commissie eerst moest bepalen dat deze bestedingseis niet in strijd was met het Europese verbod op staatssteun. ${ }^{19}$ De regering verwachtte echter weinig problemen toen zij de nieuwe maatregelen begin november 200I aanmeldde bij de Europese Commissie, omdat het oorspronkelijke pakket aan filmmaatregelen voor een periode van vijf jaar was goedgekeurd. ${ }^{20}$ 
Om te voorkomen dat er in de tussentijd geen belastingsubsidie zou zijn voor films, werd onder maatschappelijke en parlementaire druk voor het jaar 200 een overgangsregeling gecreëerd, waardoor commanditaire vennoten in een in $200 \mathrm{I}$ opgerichte film-cv aanspraak bleven houden op de ondernemersfaciliteiten. ${ }^{2 \mathrm{I}}$ Het lek naar het buitenland werd wel al in 200 gedicht: ook onder de tijdelijke maatregel moest minimaal 50\% van het budget in Nederland worden besteed.

Waar de oorspronkelijke gedachte was dat 200I alleen maar een overgangsjaar zou zijn, bleek het echter een jaar van grote onzekerheid te worden. Het begon ermee dat de pas aangetreden staatssecretaris van Financiën, Bos, in juni 200I in een interview met de Volkskrant meedeelde dat een eind zou worden gemaakt aan de aftrekbaarheid van filmbeleggingen. ${ }^{22}$ Vermoedelijk was hem ontgaan dat de overgangsmaatregel weliswaar tijdelijk was, maar dat er een nieuwe regeling klaar lag om deze op te volgen. Hij rectificeerde zijn opmerkingen dan ook al de volgende dag, ${ }^{23}$ maar het kwaad was al geschied. Beleggers werden kopschuw. Onzekerheid is immers iets waar zij niet van houden. Zoals al was gevreesd, bleek de liefde voor de film niet groot genoeg om particuliere beleggers te interesseren in tijden met grotere risico's. Anders dan de financiers van ZUSJE, waren de nieuwe filmbeleggers niet genegen een avontuur met onbekende uitkomst aan te gaan.

Het hielp hierbij niet dat de Europese Commissie eind 200I aangaf aarzeling te hebben over de 50\%-bestedingseis. ${ }^{24}$ Volgens de minister van Economische Zaken kwam de aarzeling van de Commissie als een verrassing, omdat deze bestedingseis ook al voorkwam in de in 2000 voorgelegde en in 200 I goedgekeurde overgangsregeling voor 200I. De Europese Commissie deelde echter mee niet te hebben beseft dat de overgangsregeling een bestedingsvereiste bevatte. ${ }^{25}$ Volgens de Nederlandse bewindslieden zou de visie van de Commissie op steun aan de nationale filmindustrie niet duidelijk zijn gebleken uit de mededeling van de Commissie over staatssteun aan de cinemasector. ${ }^{26}$ Deze mededeling ging onder meer over de beoordelingscriteria voor steun aan film- en tv-producties en bevatte ook een fiscale paragraaf. De mededeling staat toe dat vereist wordt dat maximaal $80 \%$ van het filmbudget in de betrokken lidstaat wordt uitgegeven en dat het steunpercentage maximaal $50 \%$ bedraagt. De eerste eis die wordt gesteld is echter dat de lidstaat controleert of de inhoud van de productie cultureel is. ${ }^{27}$ Deze vorm van staatssteun wordt namelijk toegestaan op grond van de bepaling uit het Europese verdrag die het de Commissie mogelijk maakt om staatssteun goed te keuren die de cultuur en de instandhouding van cultureel erfgoed bevordert. ${ }^{28}$ De Nederlandse filmstimuleringsmaatregelen kenden echter nadrukkelijk geen inhoudelijke toets. De films moesten primair zijn bestemd voor vertoning in bioscopen en de voortbrengingskosten mochten niet meer bedragen dan vijftien miljoen euro. Aan de film moest een projectvoorstel ten grondslag liggen, waarin moest zijn opgenomen een begroting, een financieringsplan, een verkoop- en exploitatieplan, een marketing- en promotieplan, het scenario en de synopsis en minimaal een optie op verfilmingsrechten. Het scenario moest worden ingeleverd om te beoordelen of sprake was van een film, niet zijnde een reclame- of voorlichtingsfilm, die primair bestemd was voor vertoning in 
bioscopen. ${ }^{29}$ Of aan alle gestelde vereisten werd voldaan, werd beoordeeld door Senter, een agentschap van het ministerie van Economische Zaken. Het ministerie van OCW was niet bij deze beoordeling betrokken.

\section{Onzekerheid houdt aan in 2002}

Zolang de goedkeuring van de Europese Commissie niet was verkregen, konden de nieuwe maatregelen niet worden ingevoerd. De Nederlandse overheid hoopte nog steeds dat de goedkeuring snel zou komen en verlengde de voor 200 i bedoelde tijdelijke maatregel in eerste instantie tot april 2002..$^{30}$ Omdat het besluit van de Europese Commissie langer op zich liet wachten dan was ingeschat, moest deze periode een aantal maal worden verlengd. ${ }^{3 \mathrm{I}}$ Dit gebeurde steeds met korte perioden, om problemen met de Europese Commissie te voorkomen. ${ }^{32}$ Het nadeel was echter dat door de onzekere situatie over het voortbestaan van de belastingsubsidies voor films het aantal investeringen achterbleef.

Op I9 juni 2002 kwam echter het verlossende bericht uit Brussel: de Commissie had besloten de aangemelde regeling goed te keuren op grond van voornoemde cultuuruitzondering. ${ }^{33}$ De Commissie benadrukte dat sprake moet zijn van steun voor audiovisuele producten als dragers van de nationale cultuur en niet voor ontwikkeling van een industriële activiteit. In de beschrijving van de maatregel door de Europese Commissie valt op dat de Commissie er ten onrechte van uit leek te gaan dat Fine BV in alle film-cv's deelnam en derhalve alle film-cv's aan een culturele toetsing onderwierp. De taak van Fine (een afkorting die staat voor Film Investeerders Nederland) was het koppelen van producenten met commercieel interessante filmprojecten aan investeerders. Daarnaast investeerde Fine BV zelf ook in sommige films. Fine BV kon bemiddelen bij het plaatsen van filmprojecten in commanditaire vennootschappen van banken en vermogensbeheerders. In de jaren 1999-2003 nam Fine tien keer deel in een filmproductie als arrangeur, 22 keer als investeerder en 36 keer als adviseur.34 Betrokkenheid van Fine BV werd een soort kwaliteitslabel voor film-cv's, maar Fine BV was lang niet bij alle film-cv's betrokken. Wat hier ook van zij, ervan uitgaande dat dit wel het geval was, stelde de Commissie dat sprake was van steun ten behoeve van culturele producten. De Commissie tekende hierbij aan dat de regeling afliep per 3 I december 2003 en dat de Nederlandse autoriteiten hadden meegedeeld, dat de 50\%-bestedingsvoorwaarde na 2003 niet meer zou worden gesteld. Mogelijk heeft de Commissie bij haar goedkeuring laten meewegen dat de filmmaatregelen slechts een tijdelijk karakter hadden en dat zij in eerdere instantie (bij de beoordeling van de overgangsmaatregel voor 200I) de bestedingseis had goedgekeurd, hetgeen het moeilijk zou maken deze nu af te keuren. Het onder de culturele uitzondering plaatsen van deze industrie stimulerende maatregel lijkt echter niet correct. Hoe dan ook, de Europese Commissie handelde de daaropvolgende verzoeken om tijdelijke verlenging van de belastingsubsidies voor de jaren na 2003 vervolgens vlot af. 
Op I6 juli 2002 trad de nieuwe regeling in werking. Commanditaire vennoten in een film-cv hadden vanaf die datum geen recht meer op de ondernemersfaciliteiten, maar konden nog wel gebruikmaken van de hiervoor beschreven willekeurige afschrijving van filminvesteringen en de nieuwe 'filminvesteringsaftrek'. Deze regeling hield in dat bij een filminvestering van meer dan tweeduizend euro in het jaar van investering recht op een extra aftrekpost van $47 \%$ van de filminvestering ontstond. De aftrek kon voor alle filmondernemingen van een belastingplichtige tezamen maximaal vijfentwintigduizend euro per jaar bedragen. Het verlies op de filminvestering kon echter niet meer bedragen dan de inleg in de film-cv en eventueel uit de film-cv voortkomende opbrengsten.

Het tij was echter gekeerd. Niet alleen was er de eerste helft van het jaar grote onzekerheid over het voortbestaan van de belastingsubsidies, ook mislukte in 2002 de film-cv Soldaat van Oranje 2. In de media werd uitgebreid bericht over het verlies dat de beleggers in deze film-cv leden. Dit maakte het moeilijker om beleggers voor andere film-cv's te vinden. Daarnaast zat het economisch tij tegen. Alle vier de filmcv's die nog op de valreep van de tot I5 juli 2002 verlengde overgangsregeling gebruik wensten te maken, trokken onvoldoende beleggers. 35 Beerekamps analyse luidde:

'Een paar opzienbarende deconfitures van avontuurlijke cv's deden het tij snel keren, zowel bij investeerders als bij politici. (...) Enkele opzienbarende flops, en onverkwikkelijke avonturen met gauwdieven en ander graaiziek volk bezorgden de regeling toch een uiterst negatief imago. Daarna volgde een halfslachtige politieke reactie. Het tweede paarse kabinet wilde de regeling niet helemaal afschaffen, maar besloot het de aanvragers wel zo lastig mogelijk te maken. (...) De potsierlijke verhalen over onderhandelingen met belastinginspecteurs, die als opdracht hadden om zo weinig mogelijk cv's door te laten, zullen u ongetwijfeld bereikt hebben. ${ }^{36}$

\section{Diverse afschaffingspogingen, in 2007 vervanging door directe subsidies}

In 2003 werden nog maar zo'n tien cv-films gemaakt. 37 Vooral het gebrek aan continuïteit in de regelgeving werd daaraan debet geacht. In de periode december I998mei 2003 verschenen in totaal achttien fiscale besluiten, wetten en uitvoeringsregelingen over de film-cv. ${ }^{3}$ In de woorden van de directeur van de Federatie Filmbelangen: 'Als de regels telkens veranderen kan je geen projecten opzetten.'39

Op 25 juni 2003 schreef de staatssecretaris van Financiën bovendien aan de Tweede Kamer dat de belastingsubsidies voor films niet gecontinueerd zouden worden. $4^{\circ}$ De dag erop verzocht de Tweede Kamer echter in een motie om een goede evaluatie alvorens te besluiten over de toekomst van de regeling. ${ }^{{ }^{\mathrm{I}}}$ Deze evaluatie zou de regeling zowel wat betreft het economische effect als wat betreft de culturele betekenis moeten doorlichten. Op I7 juli 2003 werd de evaluatieopdracht verstrekt 
aan adviesbureau Berenschot, dat op 4 september 2003 het evaluatierapport uitbracht. ${ }^{2}$ In het rapport staan veel negatieve ervaringen met de fiscale regeling. Volgens het rapport was het doel van de belastingsubsidie, het genereren van productievolume door het aantrekken van filmkapitaal respectievelijk het bevorderen van de filminfrastructuur, evenwel bereikt. Als geheel werden de belastingsubsidies voor films echter als niet doelmatig bestempeld. De opstellers van het rapport kwamen tot de conclusie dat 'met name meer eenduidige en consistente maatregelen met minder kosten tot eenzelfde of zelfs een beter resultaat zouden hebben geleid'.43 Op Prinsjesdag 2003, een week voor de start van het Utrechts Filmfestival, stuurde de staatssecretaris van Financiën vervolgens een wetsvoorstel naar de Tweede Kamer op grond waarvan de belastingsubsidies voor de film per I januari 2004 zouden worden afgeschaft.

De filmsector zat echter niet bij de pakken neer. De directeur van de Federatie Filmbelangen noemde het Berenschot-rapport een 'heel positief rapport' voor de filmsector.44 Ook D66 liet daags na verschijning van het rapport weten de cv-regeling te willen behouden. 45 De Volkskrant kopte: 'Filmwereld eist verlenging cv-maatregel'. ${ }^{6}{ }^{6}$ Hans Dijkstal, toenmalig voorzitter van het Filmfonds, stelde: 'Het rapport is een geweldige steun voor de Nederlandse film, die nu net op zo'n goed spoor is gekomen.' De Nederlandse Vereniging van Speelfilmproducenten noemde de beëindiging van de maatregelen in ditzelfde artikel 'onbegrijpelijk'. Het Utrechts Filmfestival 2003 speelde zich vervolgens af tegen de achtergrond van de afschaffing van de fiscale stimuleringsmaatregel. Het welkomstwoord van de directeur van dit festival, Doreen Boonekamp, was volgens de Volkskrant tevens het startschot voor de filmlobby om de Nederlandse regering af te brengen van het voornemen om het filmstimuleringsbeleid af te schaffen. 47 Dat deze lobby succesvol was, bleek uit het feit dat een meerderheid van de Tweede Kamer een motie steunde tot behoud van de belastingsubsidies in 2004. Staatssecretaris Wijn kondigde echter aan dat het na 2004 echt afgelopen zou zijn met de belastingsubsidies voor de film: 'Joop zegt sorry'. Na een intensieve lobby van de filmsector richting Kamerleden moest hij dit voornemen intrekken: dit keer werd er niet eens meer een wetsvoorstel ingediend. Eind 2004 besloot het kabinet vervolgens om het filmstimuleringsbeleid structureel voort te zetten. Het budgettaire beslag mocht echter niet meer zijn dan twintig miljoen euro per jaar, een sterke vermindering ten opzichte van de hoogtijdagen van de film-cv. Met de filmsector werd overlegd over een alternatieve vormgeving van de regeling. De gedachte dat een tijdelijke maatregel voldoende was om een gezonde Nederlandse filmindustrie te krijgen, werd losgelaten. Geconstateerd werd dat door de kleine afzetmarkt speelfilms, zelfs in het geval van een bioscoopsucces, op zichzelf geen economisch rendement bieden, om welke reden de belastingsubsidies voor een fiscaal rendement moesten zorgen. Per I januari 2006 werden de belastingsubsidies uitgebreid. Vanaf die datum werd de filminvesteringsaftrek verhoogd van $47 \%$ naar $55 \%$ en mochten participanten niet slechts I00\% van hun inleg in mindering brengen op hun inkomen, maar zelfs I30\%. De aftrekpost van de belegger in de film-cv werd daardoor groter dan zijn inleg. Voor de belegger in het hoge 
$52 \%$-tarief betekende dit dat hij van zijn inleg gegarandeerd $52 \%$ van $130=67,6 \%$ terug zou krijgen. Bij een inleg van tienduizend euro zou hij dus zijn inleg al terug hebben als hij een uitkering van 3.240 euro zou krijgen uit de cv. De nieuwe fiscale maatregelen golden tot en met 30 juni 2007, omdat per die datum de Europese goedkeuring voor de belastingsubsidies verliep. In overleg met de filmsector werden de belastingsubsidies voor film vervolgens per I juli 2007 afgeschaft. Deze afschaffing vond relatief geruisloos plaats. Zelfs zo geruisloos dat een ambtelijke werkgroep van het ministerie van Financiën die in 20 Io de mogelijkheden moest onderzoeken om tot bezuinigingen in de uitvoering van de belasting- en premieheffing te komen, nog voorstelde om de fiscale faciliteiten voor film af te schaffen..$^{8}$ Het was deze ambtenaren kennelijk ontgaan dat de faciliteiten al drie jaar eerder waren verdwenen.

Het wekt gezien de voorgeschiedenis wellicht verbazing dat er in 2007 geen ophef ontstond over het afschaffen van de fiscale faciliteiten. De reden dat de filmsector zich ditmaal niet verzette tegen afschaffing van de belastingsubsidies was vermoedelijk dat het voor de belastingsubsidies gereserveerde budget werd overgeheveld naar het ministerie van OCW. Met dit bedrag zouden voortaan directe subsidies voor films worden verstrekt. Dit was ook voor de sector aantrekkelijker dan de ingewikkelde en weinig efficiënte belastingsubsidies. De aan het opzetten van een film-cv verbonden oprichtingskosten en andere administratieve lasten waren namelijk vrij hoog,49 hetgeen de relatief omvangrijke percentages verklaart die film-cv's onder meer aan adviseurs kwijt waren. Volgens het ministerie van Financiën lagen de oprichtings- en beheerskosten van film-cv's als percentage van de totale inleg gemiddeld steeds boven de tien procent met een uitschieter naar ruim twintig procent in 2003. Ook voor de overheid was het een dure regeling. De uitvoeringskosten van de Belastingdienst bedroegen naar schatting in de periode 1999-2003 ongeveer 500.000 euro en die van Senter 328.900 euro..$^{\circ}$ Over de periode I999-2003 liep de schatkist door de filmfaciliteiten ongeveer I70 miljoen euro aan belastinginkomsten mis. ${ }^{\text {I }}$ De belastingderving was het hoogst in I999 en 2000: respectievelijk 63,6 en 75,3 miljoen euro.

De aanmelding van de vervangende directe subsidie bij de Europese Commissie had nog wel wat voeten in de aarde, maar ook die subsidie is uiteindelijk goedgekeurd tot I juli 20I3 (onder voorbehoud van tussentijds door de Europese Commissie opgelegde wijzigingen)..$^{52}$ Vermoedelijk tot opluchting van de bewindspersonen en ambtenaren op het ministerie van Financiën was het fiscale filmdossier hiermee na bijna tien jaar weer gesloten.

\section{Wat leverden de belastingsubsidies de beleggers op?}

De belastingsubsidies voor films leverden een aftrekpost op die de beleggers op het overige progressief belaste inkomen in mindering konden brengen. Hierdoor was 


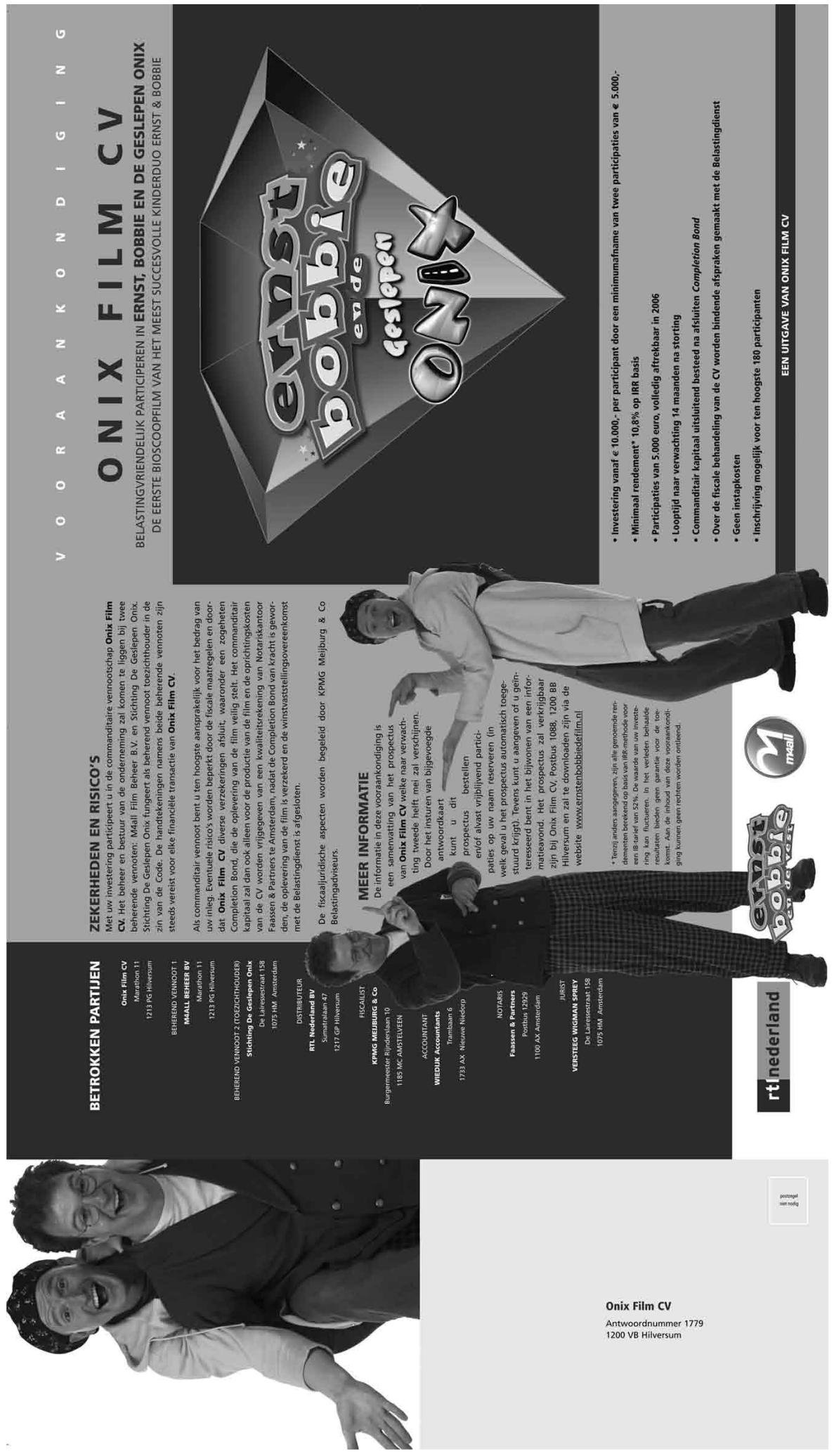




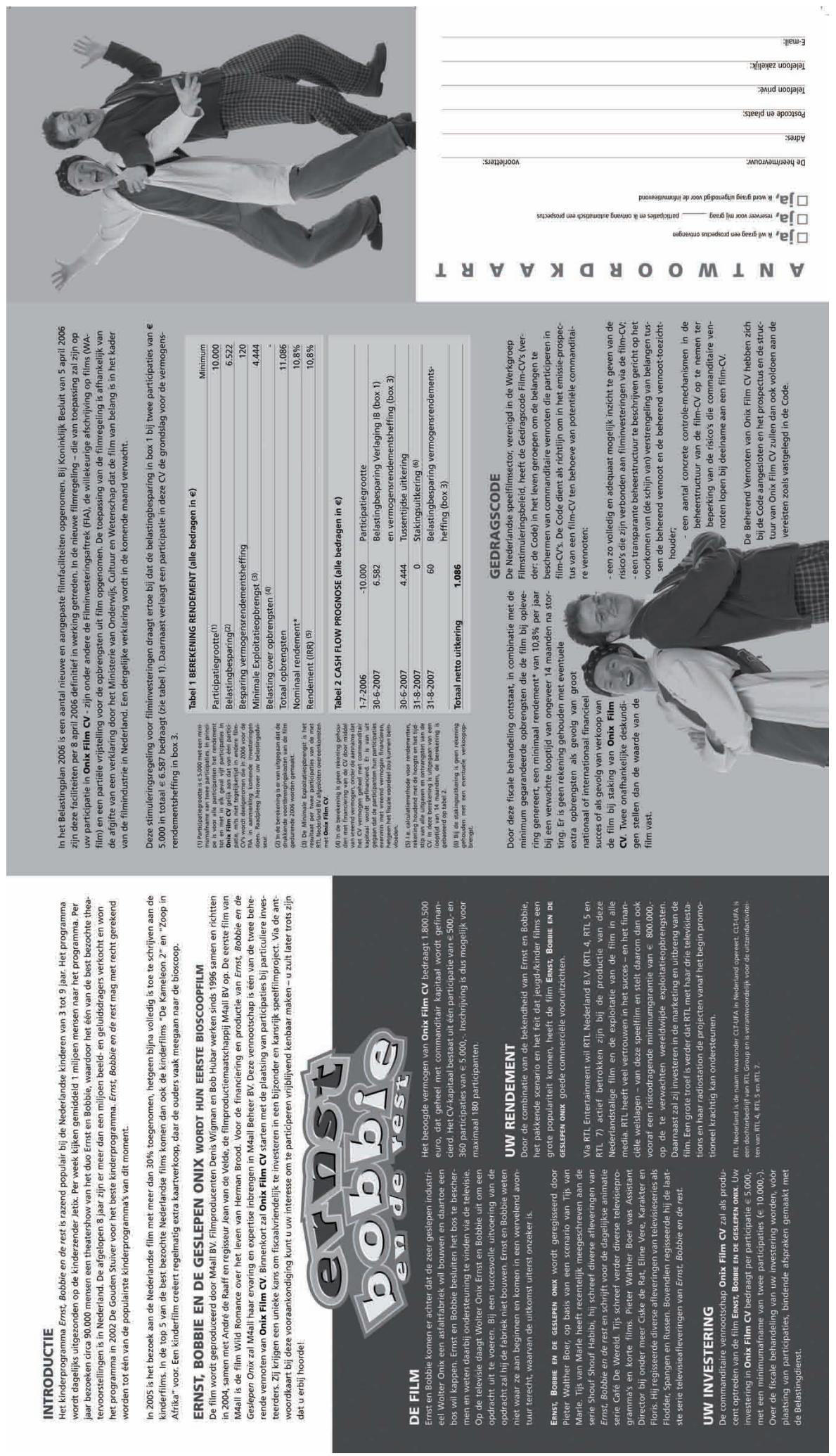


het voordeel dat door deze belastingsubsidie werd behaald groter naarmate het inkomen hoger was. De door film-cv's in het vooruitzicht gestelde rendementen werden dan ook slechts behaald door belastingplichtigen in de hoogste belastingschijf van $52 \%$. De prospectussen van de verschillende film-cv's vermeldden dan ook alleen de rendementen voor beleggers in deze hoogste schijf, zoals op pagina io van de prospectus van de CV Leef uit 2004 waarin de volgende opbrengst werd geschetst in het minimumscenario, een opbrengst die uiteindelijk ook werd gerealiseerd:

Participatiegrootte

Maximum aftrekbaar verlies

De opbrengst na aftrek van de inleg van I0.000 euro bedraagt in dit minimumscenario derhalve 5 I2 euro. Een belastingplichtige in het $42 \%$-tarief zou in dit scenario een verlies maken, omdat zijn belastingteruggaaf slechts 4.200 euro zou bedragen, waardoor zijn netto-opbrengst negatief 488 euro zou bedragen. De Volkskrant stelde daarom: 'De film-cv is een speeltje voor de rijken'.53

Bovendien blijkt uit alle prospectussen dat de filmbelegging alleen interessant is door de belastingvoordelen. Zonder deze belastingvoordelen zou de opbrengst zelfs in het meest positieve scenario negatief zijn. Zelfs als de film LEEF een groot succes was geworden, was de aan de commanditaire vennoten toekomende exploitatieopbrengst nooit meer geweest dan 6.532 euro, minder dus dan de inleg van I0.000 euro.

Interessant is ook dat het rendement niet echt werd beïnvloed door het aantal bezoekers van een film. Dit gold met name voor slecht bezochte films: door de belastingsubsidies bleef ook bij 'flops' het rendement voor de belegger op peil. De navolgende tabel54 met daarin opgenomen de verwachte en gerealiseerde rendementen van film-cv's waar het emissiekantoor WVGH bij betrokken was, illustreert dit: 
Verwachte en gerealiseerde rendementen van film-cv's (waarbij WVGH betrokken was)

\begin{tabular}{|c|c|c|c|c|c|c|}
\hline & Jaar & Film & $\begin{array}{l}\text { Aantal } \\
\text { bezoekers }\end{array}$ & $\begin{array}{l}\text { Min. rendement } \\
\text { conform } \\
\text { prospectus (IRR) }\end{array}$ & Realisatie (IRR) & $\begin{array}{l}\text { Geplaatst } \\
\text { kapitaal } \\
\text { door WVGH }\end{array}$ \\
\hline I & 2000 & MAGONIA & 16.000 & $6,10 \%$ & $6,10 \%$ & 828.149 \\
\hline 2 & 2000 & ZUS \& ZO & 4т. 868 & $8,50 \%$ & $8,50 \%$ & 2.096 .465 \\
\hline 3 & 2000 & MINOES & 837.372 & $\mathrm{I} 3,40 \%$ & $25,00 \%$ & I.I34.450 \\
\hline 4 & 2001 & SOLDAAT VAN ORANJE 2 & $\circ$ & $4,10 \%$ & $-9,00 \% 55$ & 3.970 .576 \\
\hline 5 & $200 \mathrm{I}$ & PIETJE BELL I & 820.760 & $4,50 \%$ & $2,00 \%$ & I.730.037 \\
\hline 6 & $200 \mathrm{I}$ & DE OESTERS VAN NAMKEE & 143.624 & $6,00 \%$ & $6,00 \%$ & 887.367 \\
\hline 7 & $200 \mathrm{I}$ & JA ZUSTER NEE ZUSTER & 460.544 & $3,80 \%$ & $3,10 \%$ & 2.032 .935 \\
\hline 8 & 2002 & VOLLE MAAN & 454.672 & $3,70 \%$ & $\mathrm{I} 4,00 \%$ & I.78I. 598 \\
\hline 9 & 2002 & PHILEINE ZEGT SORRY & 296.766 & $5,50 \%$ & $5,50 \%$ & 3.IIO.000 \\
\hline IO & 2003 & KEES DE JONGEN & 60.637 & $5,00 \%$ & $5,00 \%$ & 445.000 \\
\hline II & 2003 & AMAZONES & 26.563 & $6,20 \%$ & $6,20 \%$ & I. 040.000 \\
\hline $\mathrm{I} 2$ & 2003 & $\begin{array}{l}\text { ERIK OF HET KLEIN } \\
\text { INSECTENBOEK }\end{array}$ & II 2.369 & $6,20 \%$ & $6,20 \%$ & I.4I0.000 \\
\hline I3 & 2004 & LEEF & I00.000 & $5,70 \%$ & $5,70 \%$ & 400.000 \\
\hline $\mathrm{I} 4$ & 2004 & JOHAN & 31.000 & $6,00 \%$ & $6,00 \%$ & 2.285 .000 \\
\hline I5 & 2005 & HERMAN BROOD & 27.000 & $8,60 \%$ & $8,20 \%$ & I. 655.500 \\
\hline I6 & 2006 & ALLES IS LIEFDE & I.I33.605 & $8,20 \%$ & $25, \mathrm{I} \%$ & 2.535 .000 \\
\hline
\end{tabular}

Deze cijfers bevestigen dat het rendement op de filmbelegging vaak los stond van het succes van de film, iets wat bij een normale, niet-fiscaal gesubsidieerde belegging niet snel het geval zal zijn. De belastingsubsidies leverden derhalve geen bijdrage aan een vergroting van de marktoriëntatie van de Nederlandse filmindustrie, een van de subdoelstellingen van het pakket stimuleringsmaatregelen voor de Nederlandse filmindustrie. De belastingsubsidies vormden immers nauwelijks een stimulans voor het maken van commercieel succesvolle films. De film HERMAN BROOD trok bijvoorbeeld slechts 27.000 bezoekers, maar leverde wel een rendement op van $8,20 \%$. De film JA ZUSTER NEE ZUSTER, die een veelvoud aan bezoekers trok, leverde de beleggers echter slechts een rendement van 3,I\%. Slechts bij de grote publiekstrekkers MINOES en ALLES IS LIEFDE en in mindere mate VOLLE MAAN zagen de beleggers bezoekersaantallen terug in hun rendement. Een filmbelegging was door de genereuze belastingsubsidies een relatief risicoloze belegging met een vrij groot minimumrendement en bij succes een kans op een extra rendement. De film kwam daardoor steeds meer op de achtergrond te staan: de meeste beleggers maakte het niet zoveel uit waar ze precies in investeerden. Van het kweken van particuliere betrokkenheid bij de filmindustrie was dan ook geen sprake. Tijdens de bijeenkomsten waarin de film-cv's aan de man werden gebracht, werd soms pijnlijk 
duidelijk dat het in film-cv's geïnteresseerde publiek primair belangstelling had voor het rendement en niet in de te financieren film. De observatie van filmrecensent Bas Blokker bij de bijeenkomst voor potentiële beleggers in de film zUS \& zO bevestigt dit beeld: "In het eerste gedeelte van de avond praten wij over de film", zegt presentator René Mioch nadat hij zijn publiek heeft verwelkomd. "In het tweede deel praten wij over de fiscale regeling." In het zaaltje gaat een vinger omhoog. "Kunt $u$ de volgorde ook omdraaien?" ${ }^{6} 6$ De maatregelen bleken niet zozeer tot liefde voor de Nederlandse film te leiden, maar schiepen primair een lucratief financieel product. Omdat de belastingsubsidies geen betrokkenheid bij films creëerden, leidden deze niet tot een duurzame belangstelling van beleggers voor films. Dit werd duidelijk toen films als beleggingsproduct minder interessant werden en de beleggers de film snel de rug toekeerden. Aan het creëren van een economisch levensvatbare filmsector die zonder overheidssteun zou kunnen voortbestaan (de hoofddoelstelling van het totale pakket ter stimulering van de Nederlandse filmindustrie) droegen de belastingsubsidies derhalve niet bij.

\section{Wat hebben de belastingsubsidies de Nederlandse film opgeleverd?}

De directeur van het Utrechts Filmfestival stelde in de Dagkrant Nederlands Filmfestival van 25 september 2003: 'It is necessary that we fight for these financial policies to be continued so that we can see good Dutch films in the future.' Het is echter de vraag of zonder de film-cv geen goede Nederlandse films zouden zijn gemaakt. Om het belang van de film-cv te onderstrepen, werden steevast dezelfde films genoemd: MINOES, JA ZUSTER NEE ZUSTER, VOLLE MAAN, THE DISCOVERY OF HEAVEN En NYNKE. 57 In de jaren 1999-2003 konden de producenten dankzij de stimuleringsmaatregelen beschikken over zo'n 200 miljoen euro, terwijl ze het anders met maximaal 65 miljoen euro hadden moeten doen..$^{8}$ In NRC Handelsblad stelde Bas Blokker echter de vraag: 'Waren het nou allemaal films die zonder fiscale steun niet te maken waren geweest? Waren ze allemaal wel zo succesvol? En waren ze wel allemaal zo goed?'59 Hij wijst op het grote aantal weinig opzienbarende, primair internationaal georiënteerde en goede, maar weinig succesvolle films dat de film-cv's hebben opgeleverd: 'Via de film-cv ging kortom wel veel belastinggeld de filmwereld in, maar veel bijzonders leverde het nog niet op. ${ }^{60}$ Wel ziet hij na THE DISCOVERY OF HEAVEN een mentaliteitsverandering: Nederlandse films worden in een veel groter aantal kopieën uitgebracht en zijn daardoor in veel meer bioscopen te zien en ze trekken veel meer publiek. Dit geldt echter ook voor niet-cv-films. Het extra commerciële succes van de laatste jaren verklaart Blokker vooral uit de productie van doelgroepenfilms voor GTST-publiek ${ }^{61}$ en de jeugd. Ook Trouw-recensent Jann Ruyters merkte op:

'De grotere bezoekersaantallen zitten bij de boekverfilmingen (die altijd al veel bezoekers trokken), bij de kinderfilms en bij de met soapsterren bevolkte com- 
merciële producties als COSTA! en LIEVER VERLIEFD. De meer artistieke film (zoals het geprezen VAN GOD LOS over de bende van Venlo) trekt ongeveer hetzelfde aantal mensen als vroeger. ${ }^{62}$

En Beerekamp concludeerde: 'de essentie is dat de regeling een paar schandalen heeft opgeleverd, en een bescheiden aantal door publiek én filmpers hoog gewaardeerde films (MINOES, THE DISCOVERY OF HEAVEN, NYNKE)'. ${ }^{6} 3$

In de Volkskrant hield Ronald Ockhuysen een pleidooi voor minder focus op het behoud van de fiscale stimuleringsmaatregelen en meer lef en persoonlijkheid 'zodat de Nederlandse film ook weer eens aanwezig is op de prestigieuze festivals van Cannes en Venetië'. ${ }^{64}$ Bovendien bleken er in de jaren 1999-2004 meer Nederlandse films te zijn gemaakt zonder (75) dan met (60) fiscale steun. De Volkskrant vond dan ook dat dit verschil opmerkelijk is, omdat de filmwereld stelde dat zonder fiscale steun er een 'kaalslag' dreigde in de Nederlandse film. De krant wees erop dat bij de films die op eigen kracht zijn gemaakt niet de minste zitten. Genoemd worden DE TWEELING, VAN GOD LOS en 'het succesvolle COSTA'.65 DE TWEELING werd voor de Oscaruitreikingen 2004 genomineerd als beste buitenlandse film en won het Gouden Kalf voor beste film. Dat er zonder film-cv's geen goede Nederlandse films kunnen worden gemaakt, blijkt derhalve niet uit de feiten. Bovendien was de maatregel niet primair gericht op het maken van 'goede' films. Ook is het de vraag of alleen dankzij de film-cv Nederlandse films weer in de gratie zijn van het publiek. Zou er niet evenals bij bijvoorbeeld musicals en cabaret sprake kunnen zijn van een slingerbeweging van perioden waarin een bepaalde kunstvorm meer of minder populair is? Uit het onderzoek van Hofstede blijkt dat het bezoek aan Nederlandse films sinds de jaren zeventig steeds aan schommelingen onderhevig is geweest. ${ }^{66}$ In I982, toen er nog geen belastingsubsidies voor films waren, schreef Van den Berg:

'Het gaat verhoudingsgewijs goed met de Nederlandse speelfilm. In I979 vormden de uitgebrachte Nederlandse films niet meer dan $4 \%$ van het totaal aantal titels (320) dat uitkwam, de recette op deze films bedroeg echter II, $5 \%$ van de totale recette. Van de twintig succesvolste films waren er liefs vijf van Nederlands fabrikaat. De bioscoopbezoeker heeft blijkbaar een voorkeur voor films van eigen bodem. ${ }^{67}$

Hofstedes conclusie was dat de belangstelling voor de Nederlandse film zich opvallend goed staande heeft weten te houden. ${ }^{68}$ Ook zonder fiscale maatregelen was de Nederlandse film kennelijk populair. Feit is wel dat een van de allerlaatste films die met gebruikmaking van de fiscale faciliteiten is gemaakt, ALLES IS LIEFDE, in het najaar van 2007 een enorme hit is geworden. Niet alleen in bezoekersaantallen, maar ook in het rendement dat deze film de beleggers heeft opgeleverd, was sprake van een groot succes. Het blijft echter de vraag of deze film niet ook zonder de fiscale faciliteiten gemaakt had kunnen worden. 


\section{Conclusie}

De filmfaciliteiten bleken een schoolvoorbeeld van hoe belastingsubsidies niet moeten worden ingezet om kunst en cultuur te stimuleren. De vormgeving was, zeker na de invoering van de Wet Inkomstenbelasting 200I ingewikkeld. De doelstelling van de faciliteiten was niet helder en daardoor ook moeilijk te toetsen. Het was zeer de vraag of de faciliteiten wel in overeenstemming waren met de Europese regelgeving, waardoor het lang duurde voordat de Europese Commissie goedkeuring gaf aan aanpassingen van de faciliteiten. Dit leidde tot grote onzekerheid voor de Nederlandse filmindustrie en potentiële beleggers. Door de fiscale voorzieningen was er bovendien nauwelijks een verband tussen het succes van een film en de opbrengsten voor de beleggers. De faciliteiten droegen daarom niet bij aan een vergroting van de marktoriëntatie van de filmindustrie en het streven naar commercieel succesvolle films. De faciliteiten deden vooral een beroep op beleggers en hadden niet de intentie om van deze beleggers liefhebbers te maken. Hierdoor kweekten die tegemoetkomingen geen betrokkenheid tussen particuliere financiers en de filmwereld. Toen de rendementen minder dreigden te worden door onzekerheid over het voortbestaan van de regeling, keerden de beleggers de film dan ook weer de rug toe. De kosten van de oorspronkelijke regeling waren bovendien vele malen hoger dan vooraf ingeschat, waardoor het voor de overheid een dure subsidieregeling werd. Niettemin werden de faciliteiten ondanks slechte evaluaties onder druk van lobbyisten nog geruime tijd in stand gehouden. Pas toen het mogelijk was om het budget voor de filmtegemoetkomingen over te hevelen naar het ministerie van OCW, staakte de sector zijn verzet tegen afschaffing van de faciliteiten. De belastingsubsidies voor de film-cv zijn vervolgens de fiscale geschiedenisboeken ingegaan als hét schoolvoorbeeld van hoe belastingen niet moeten worden gebruikt om politieke doelen te bereiken.

\section{Noten}

I M. Doppert, 'Organisatorisch brein achter ZUSJE versiert sponsors', in: Folia, nr. 2I, januari I997. Behalve dit interview met de producent van de film, Clea de Koning, zijn als bronnen over de film zUSJE onder meer de volgende krantenartikelen gebruikt: 'ZUSJE als beste film bekroond met Gouden Kalf, in: de Volkskrant, 30 september I995; T. Mooij, 'Robert Jan Westdijk: Hard werken aan spontaniteit', in: de Filmkrant, nr. I63, januari I996; P. van Bueren, 'Uniek avontuur van ZUSJE' in: de Volkskrant, 29 juni I996.

2 Overigens was ook de producent van de film, Clea de Koning, in eerste instantie een soort natura verstrekking. Toen Westdijk haar vader om geld vroeg voor zijn film bood hij aan dat zijn dochter, die op dat moment 'in between jobs' was een aantal weken op zijn kosten met hem zou werken.

3 Ministeriële regeling 7 december I998, nr. WDB 98/4I3; Staatscourant, I4 december I998, nr. 239.

4 Aldus de staatssecretaris van Financiën in het nader rapport bij het wetsvoorstel Wijziging van belastingwetten c.a. (Belastingplan 2002 II- Economische infrastructuur), Kamerstukken II, 200I-2002, 28034, A.

5 Kamerstukken II, I997-I998, 25 688, B, p. 3.

6 Kamerstukken II, I997-I998, 25 688, nr. 3, p. 4-5. 
7 Research voor beleid, Stimuleringsmaatregelen filmindustrie, tussentijdse evaluatie - Eindrapport, Leiden, I4 maart 200I. Onderzoek in opdracht van het ministerie van Economische Zaken, op II juni 200I aan de Tweede Kamer aangeboden.

8 B. Blokker, 'Beleggen in Nederlandse speelfilms. Durfkapitaal zonder risico', in: NRC Handelsblad, 29 september 2000.

9 Kamerstukken II, 200I-2002, 25 434, nr. 9.

IO B. Dirks \& P. Klok, 'Investeren in film toch een rendabele hobby', in: de Volkskrant, 8 juni 2002.

II H. Beerekamp, 'Geachte heer Dijkstal', in: NRC Handelsblad, 29 maart 2003.

I2 Blokker, 'Beleggen in Nederlandse speelfilms'.

I3 G-J. Bron, 'Baantjer is de norm', in: de Volkskrant, I3 december 2003.

I4 Research voor beleid, Stimuleringsmaatregelen filmindustrie.

I5 Beerekamp, 'Geachte heer Dijkstal'.

I6 J. Schoorl \& B. Wagendorp, 'Rode loper naar de filmhemel', in: de Volkskrant, 24 oktober 20 Io.

I7 Zie voor een samenvatting van dit debat P.B. Engelen, 'Het ingrijpen van de staatssecretaris van Financiën in de aanslagregeling', in: Weekblad fiscaal recht, I985/5708, p. I639 e.v., en P.B. Engelen, 'Het ingrijpen van de staatssecretaris van Financiën in de aanslagregeling', in: Weekblad fiscaal recht, ig $86 / 5728$, p. 602 e.v.

I8 'Groot aanbod op Nederlands filmfestival door cv-films', in: de Volkskrant, 5 september 200I, en R. Ockhuysen, 'Zonder dikke sigaar', in: de Volkskrant, 20 september 200 I.

I9 Met ingang van I december 2009, staat dit verbod in artikel I07 van het Verdrag betreffende de werking van de Europese Unie (afgekort VwEU).

20 Brief minister van Economische Zaken van Io april 2002, Kamerstukken II, 200I-2002, 25 434, nr. I3.

2I Artikel Dd Invoeringswet Wet inkomstenbelasting 200I (Tijdelijke tegemoetkoming film 200I).

22 'Filmbelegging niet langer aftrekbaar', in: de Volkskrant, I2 juni 200I, en P. Klok, 'Bos verstoort idylle filmbeleggers', in: de Volkskrant, I2 juni $200 \mathrm{I}$.

23 P. Klok, 'Investeren in film blijft aantrekkelijk', in: de Volkskrant, I3 juni $200 \mathrm{I}$.

24 Brief minister van Economische Zaken van Io april 2002, Kamerstukken II, 200I-2002, 25 434, nr. I3.

25 Kamerstukken II, 200I-200I, 25 434, nr. I5, p. 3.

26 De minister doelde op: Mededeling van de Commissie aan de Raad, aan het Europese Parlement, aan het Economisch en Sociaal Comité en aan het Comité van de regio's over bepaalde juridische aspecten in verband met cinematografische en andere audiovisuele werken, СОM(200I) 534, 26 september 200I.

27 Op pagina 8, onder het kopje 'Specifieke verenigbaarheidscriteria betreffende staatssteun voor productie van film- en tv-programma's'.

28 Met ingang van I december 2009, artikel Io7, lid 3, onderdeel d VwEU.

29 Toelichting op artikel 2 van de Regeling aanwijzing filminvesteringen 2002.

$30 \mathrm{Bij}$ besluit van 28 december $200 \mathrm{I}$ (nr. CPP200I/3658M) tot I april 2002, maar uiterlijk tot het tijdstip van inwerkingtreding van de regeling voor de filminvesteringsaftrek.

3I Bij besluit van 28 februari 2002 ( $\mathrm{nr}$. CCP2002/622M) tot I april 2002, bij besluit van 28 maart (nr. CCP2O02/IO35M) tot I mei, bij besluit van 23 april 2002 (nr. CCP2002/I255M) tot en met I5 juli 2002.

32 Kamerstukken II, 200I-200I, 25 434, nr. I5, p. 2.

33 Brief d.d. I9 juni 2002, nr. C (2002) 2138fin.

34 B. Drenth, B. den Boer-Drinkenburg, M. Pen, J. Gelevert, F. Doornbos, Evaluatie van de stimuleringsmaatregelen voor de Nederlandse film 1999/2003, Utrecht 2003, p. 30.

35 Het betrof twee door Fine ondersteunde cv's, te weten de cv waarin de film PHILEINE ZEGT SORRY (naar het boek van Ronald Giphart) en de cv waarin GRIMM (van Alex van Warmerdam) zou worden gemaakt. Daarnaast ging ook de cv FOUR AMERICAN MOVIES niet door.

36 Beerekamp, 'Geachte heer Dijkstal'.

37 M. Luijt, 'Tien projecten voor één film', in: NRC Handelsblad, 29 maart 2003.

38 Een overzicht van deze regelgeving is opgenomen in Drenth e.a., Evaluatie van de stimuleringsmaatregelen, p. 37-4I.

39 Luijt, 'Tien projecten voor één film'. 
40 Brief staatssecretaris van Financiën van 25 juni 2003, nr. WDB 2003-240U, VN 2003/32.9.

4I Kamerstukken II, 2002-2003, 28880 en 28 929, nr. 94.

42 Drenth e.a., Evaluatie van de stimuleringsmaatregelen.

43 Ibidem, p. 56.

44 J.P. Ekker, 'Evaluatie cv-regeling film heeft doelstelling niet gehaald', in: de Volkskrant, I6 september 2003 .

45 'D66 wil steun Nederlandse film behouden', in: NRC Handelsblad, I8 september 2003.

46 'Filmwereld eist verlenging cv-maatregel', in: de Volkskrant, I9 september 2003.

47 J.P. Ekker \& R. Ockhuysen, 'Film en lobby in Utrecht begonnen', in: de Volkskrant, 25 september 2003 .

48 Rapport van Werkgroep 16, Uitvoering belasting- en premieheffing, Den Haag 20I0, onderdeel 3.8.5, p. 56 .

49 Drenth e.a., Evaluatie van de stimuleringsmaatregelen, p. Iо.

50 Ibidem, p. 46.

5 I Ibidem, p. 47.

52 Brief van Io juli 2007, C (2007) 3I3I def. inzake Steunmaatregel N 29I/2007.

53 Dirks \& Klok, 'Investeren in film toch een rendabele hobby'.

54 Bron: http://www.wvgh.nl/content/view/I5/13/lang,nl/\#.

55 Deze film is niet gemaakt, waardoor de beleggers wel met een echt verlies werden geconfronteerd.

56 Blokker, 'Beleggen in Nederlandse speelfilms'.

57 Zie onder meer B. Dirks \& P. Klok, 'Belastingdienst helpt film aan 5 procent rendement', in: de Volkskrant, 23 april 2003; B. Blokker, 'Terug naar Flevoland. Nederlandse film verdient vertrouwen', in: NRC Handelsblad, I9 september 2003; J. Ruyters, 'Nèt nu het zo goed ging', in: Trouw, 24 september 2003; 'Film vreest verdwijnen cv-gelden', in: de Volkskrant, I9 mei 2003; R. Ockhuysen, 'CV-regeling: Nederland kan zijn plek in de marge weer innemen', in: de Volkskrant, 22 mei 2003; A. van Driel \& J. Ramaer, 'Bezuinigingen op cultuur vallen erg mee', in: de Volkskrant, 27 mei 2003; 'Steunbeleid film geen blijvend succes', in: NRC Handelsblad, I6 september 2003.

58 Blokker, 'Terug naar Flevoland'.

59 Ibidem.

6o Ibidem.

6I De afkorting GTST staat voor Nederlands langst lopende soap GOEDE TIJDEN SLECHTE TIJDEN.

62 Ruyters, 'Nèt nu het zo goed ging'.

63 H. Beerekamp, 'Het publiek weet wel beter. Een Nederlandse filmindustrie is een hersenschim', in: NRC Handelsblad, 6 april 2002.

64 R. Ockhuysen, 'Filmcultuur bloeit niet alleen op geld', in: de Volkskrant, 4 oktober 2003.

$6_{5}$ F. Haan, 'Meerderheid films zonder cv gemaakt', in: de Volkskrant, I4 oktober 2003.

66 B. Hofstede, Nederlandse cinema wereldwijd, Amsterdam 2000, p. 55, 6I en I5I-I53.

67 H.O. van den Berg, 'Overheid en kunst', in: ESB, nr. 3370, I982, p. 904-9I3, p. 9I2.

68 Hofstede, Nederlandse cinema wereldwijd, p. 6I. 